

\section{Nultinational Corporations}

in Politicial Environments

Ethics, Values and Strategies

\section{Usha C. V. Haley}

The University of Tennessee, Knoxville, USA 
Published by

World Scientific Publishing Co. Pte. Ltd.

P O Box 128, Farrer Road, Singapore 912805

USA office: Suite 1B, 1060 Main Street, River Edge, NJ 07661

UK office: 57 Shelton Street, Covent Garden, London WC2H 9HE

\section{British Library Cataloguing-in-Publication Data}

A catalogue record for this book is available from the British Library.

\section{MULTINATIONAL CORPORATIONS IN POLITICAL ENVIRONMENTS Ethics, Values and Strategies}

Copyright $\odot 2001$ by World Scientific Publishing Co. Pte. Ltd.

All rights reserved. This book, or parts thereof, may not be reproduced in any form or by any means, electronic or mechanical, including photocopying, recording or any information storage and retrieval system now known or to be invented, without written permission from the Publisher.

For photocopying of material in this volume, please pay a copying fee through the Copyright Clearance Center, Inc., 222 Rosewood Drive, Danvers, MA 01923, USA. In this case permission to photocopy is not required from the publisher.

ISBN 981-02-4427-4

Printed in Singapore by Mainland Press 


\section{For George T. Haley}


This page is intentionally left blank 


\section{About the Author}

Usha C. V. Haley (PhD, Stern School of Business, New York University) is Associate Professor of Management, focusing on Strategic Management and International Business, in the College of Business Administration at the University of Tennessee, Knoxville. She has more than 70 books, journal articles, book chapters and research presentations on international strategic management. Her latest books include New Asian Emperors: The Overseas Chinese, their Strategies and Competitive Advantages (ButterworthHeinemann); Strategic Management in the Asia Pacific: Harnessing Regional and Organizational Change for Competitive Advantage (ButterworthHeinemann); and, Asian Post-Crisis Management: Corporate and Governmental Strategies for Sustainable Competitive Advantage (Macmillan/ Palgrave). She also has a forthcoming book on Asia's Tao of Business: The Logic of Chinese Business Strategy (Wiley). She has taught International Business and Strategic Management at major universities in the United States (including Harvard University), Singapore (at the National University of Singapore), Australia (at the Australian National University), and Mexico (at ITESM, Monterrey Campus). Additionally, she has taught in major corporate, governmental and universities' executive-development programs, for top and middle managers and policy makers, in the United States, Australia, Mexico, Vietnam, Italy, India and Singapore. She also serves as a consultant on issues concerning strategic management and foreign direct 
viii Multinational Corporations in Political Environments

investment for several multinational corporations in North America, Australia, Europe and Asia and as Regional Editor (Asia Pacific) for two academic journals. Please contact her at uhaley@asia-pacific.com. 


\section{CONTENTS}

Foreword xviii

Acknowledgements $\quad$ xxi

PART I INTRODUCTION 1

1. Overview and Outline 3

PART II MULTINATIONAL CORPORATIONS AS
CATALYSTS

2. Multinational Corporations as Change Agents 11

Rationales for Presence $\quad 12$

Rationales for Entry $\quad 12$

Market Imperfections $\quad 12$

Internalization $\quad 15$

$\begin{array}{ll}\text { Strategic Management } & 17\end{array}$

Manufacturing. Processes 17

Oligopolistic Markets $\quad 19$

Rationales for Growth $\quad 19$

Market Imperfections $\quad 20$

Internalization 20

Strategic Management $\quad 21$ 
x Multinational Corporations in Political Environments

Rationales for Decline $\quad 22$

Internalization $\quad 22$

Strategic Management 23

Relations with Stakeholders $\quad 24$

Owners and Managers $\quad 24$

Market Imperfections $\quad 25$

Internalization $\quad 26$

Strategic Management 26

$\begin{array}{ll}\text { Labor } & 27\end{array}$

Manufacturing Process 27

Governments $\quad 28$

Oligopolistic Markets $\quad 28$

Redistribution $\quad 29$

States $\quad 32$

International Relations 32

Societies $\quad 35$

Dependent Development 36

$\begin{array}{ll}\text { The World } & 38\end{array}$

Global Networks $\quad 38$

Theoretical Assumptions $\quad 39$

Static Analytical Schemes $\quad 39$

Efficient Control and Coordination $\quad 40$

Stable Relations with Stakeholders $\quad 40$

3. Reassessing Theories of Multinational

$\begin{array}{ll}\text { Corporations } & 42\end{array}$

Dynamic Analytical Schemes $\quad 42$

Illusory Control and Coordination $\quad 47$

Shifting Relations with Stakeholders $\quad 49$

4. Applying the Theories to South Africa during Apartheid $\quad 53$

Explaining Multinationals' Behaviors $\quad 53$

Union Carbide $\quad 55$ 
General Motors (GM) $\quad 55$

Revlon 55

International Business Machines (IBM) 55

Goodyear $\quad 56$

Conclusions $\quad 56$

Leaving or Staying in South Africa $\quad 57$

Total Liquidation and Piecemeal Sale of Assets 58

Sale to South African or European Company 59

Sale to another US Company $\quad 60$

Sale to Local Management $\quad 60$

Formation of Trust $\quad 62$

No Additional Investment by US Headquarters 63

Increased Investment by US Headquarters $\quad 64$

Summary 65

PART III MULTINATIONAL CORPORATIONS

AS CHAMELEONS $\quad 67$

5. The Development of Multinational Corporations 69

Forces for Organizational Development 69

Environmental Determinism $\quad 70$

Purposeful Actions $\quad 71$

$\begin{array}{ll}\text { Power } & 72\end{array}$

Rationales for Organizational Development $\quad 73$

Rationales for Growth $\quad 74$

Technical-Efficiency Forces $\quad 74$

Ideological Forces $\quad 75$

Political Forces $\quad 75$

Rationales for Consolidation $\quad 77$

Technical-Efficiency Forces $\quad 79$

Ideological Forces $\quad 81$

Political Forces $\quad 82$

Rationales for Decline 84

Technical-Efficiency Forces $\quad 85$ 
xii Multinational Corporations in Political Environments

Ideological Forces $\quad 86$

Political Forces $\quad 86$

Relations with Stakeholders over Time $\quad 88$

6. Why Multinational Corporations Leave Host States 92

A Political-Action Framework for Multinationals 93

Sources for Inertia $\quad 96$

Sources for Metamorphic Change 100

Hypothesizing why a Multinational may Leave 103

Headquarters' Inducements to Stakeholders 104

Links to Headquarters' Actions on

Subsidiary's Presence $\quad 105$

Voice and Exit Actions of Headquarters'

Stakeholders

105

Links to Headquarters' Actions on

Subsidiary's Presence

106

Headquarters' Inducements to Stakeholders as a Mediator

106

Links between Voice and Exit Actions of

Headquarters' Stakeholders

107

Dominant Coalition's Stability

107

Links to Voice and Exit Actions of

Headquarters' Stakeholders

107

Links to Headquarters' Actions on

Subsidiary's Presence

108

Links to Dominant Coalition's Benefits 109

Multinational's Competitive Strategies $\quad 110$

Links to Dominant Coalition's Benefits $\quad 110$

Links to Headquarters' Actions on

Subsidiary's Presence

Subsidiary's Symbolic Actions

Links to Headquarters' Actions on

Subsidiary's Presence

113

Headquarters' Inducements to Stakeholders

as a Mediator 
Subsidiary's Profits and Importance in

Global Operations

Links to Headquarters' Actions on

Subsidiary's Presence

Subsidiary's Noncompetitive Strategies with

Host State

Links to Subsidiary's Symbolic Actions

Links to Subsidiary's Profits

Links to Headquarters' Actions on

Subsidiary's Presence

Suppression of Voice and Exit Actions by Host State

Links to Subsidiary's Symbolic Actions

Links to Subsidiary's Profits

Links to Subsidiary's Noncompetitive

Strategies with Host State

Links to Headquarters' Actions on Subsidiary's Presence

Links to Subsidiary's Symbolic Actions

Links to Suppression of Voice and Exit Actions by Host State

Summary

7. Methodology

The Setting

The Time Frame 128

The Population $\quad 132$

The Variables

Headquarters' Actions on Subsidiary's

Presence (PRESENCE) 
xiv Multinational Corporations in Political Environments

Headquarters' Inducements to Stakeholders

(INDUCE1 and INDUCE2)

Measurement

Primary Sources of Data and Checks

Voice and Exit Actions of Headquarters'

Stakeholders (SR, SD, GP and GD)

Measurement

Primary Sources of Data and Checks

Dominant Coalition's Stability (TMT)

Measurement

Primary Sources of Data and Checks

Dominant Coalition's Benefits (BENEFITS)

Measurement

Primary Sources of Data and Checks

Multinational's Competitive Strategies (ADVERTISING, RESEARCH, DIVERSIFY, BACKLOGS and INTEGRATION)

Measurement

Primary Sources of Data and Checks

Subsidiary's Symbolic Actions (SYMBOL)

Measurement

Primary Sources of Data and Checks

Subsidiary's Profits (ROA)

Measurement

Primary Sources of Data and Checks

Subsidiary's Importance in Global Operations (ASSETS, SALES and EMPLOYEES)

Measurement

Primary Sources of Data and Checks

Subsidiary's Noncompetitive Strategies with

Host State (CONTRACT and COOPT)

Measurement

Primary Sources of Data and Checks 
Suppression of Voice and Exit Actions by Host State (SUPPRESS)

Measurement

Primary Sources of Data and Checks

Subsidiary's Inducements to Host State

(INDUCE3)

Measurement

Primary Sources of Data and Checks

Summary

8. Analyses and Results

The Analyses

The Analytical Models $\quad 165$

The Results

Voice and Exit Actions of Headquarters'

Stakeholders

Links to Headquarters' Actions on

Subsidiary's Presence

Dominant Coalition's Stability

Links to Headquarters' Actions on

Subsidiary's Presence

Links to Voice and Exit Actions of

Headquarters' Stakeholders

Multinational's Competitive Strategies

Links to Headquarters' Actions on

Subsidiary's Presence

178

Links to Dominant Coalition's Benefits

Subsidiary's Symbolic Actions

Links to Headquarters' Actions on

Subsidiary's Presence

Subsidiary's Profits and Importance in

Global Operations

Links to Headquarters' Actions on

Subsidiary's Presence 
xvi Multinational Corporations in Political Environments

Subsidiary's Noncompetitive Strategies with

Host State

192

Links to Headquarters' Actions on

Subsidiary's Presence

192

Links to Subsidiary's Symbolic Actions

193

Suppression of Voice and Exit Actions by

Host State

195

Links to Headquarters' Actions on

Subsidiary's Presence

Links to Subsidiary's Symbolic Actions

Links to Subsidiary's Noncompetitive

Strategies

196

Subsidiary's Inducements to Host State

198

Links to Subsidiary's Symbolic Actions

198

Summary

198

Generalizability of the Results

198

PART V THEORETICAL AND STRATEGIC IMPLICATIONS

201

9. Understanding and Influencing Multinational

Corporations

203

Understanding Multinationals 203

Decoding the Results 204

Voice and Exit Actions of Headquarters'

Stakeholders

205

Dominant Coalition's Stability

206

Multinational's Competitive Strategies

206

Subsidiary's Symbolic Actions

207

Subsidiary's Profits and Importance in

Global Operations

207

Subsidiary's Noncompetitive Strategies

with Host State

208

Suppression of Subsidiary's Voice and Exit

Actions by Host State

209 
Future Research 209

Influencing Multinationals $\quad 212$

Sanctioning Myanmar $\quad 212$

Monitoring Nike $\quad 219$

Questions for the Future $\quad 222$

$\begin{array}{ll}\text { References } & 227\end{array}$

$\begin{array}{ll}\text { Index } & 259\end{array}$ 
This page is intentionally left blank 


\section{Foreword}

\section{By Ingo Walter:}

This volume represents a valuable addition to the literature on the multinational firm, which dates back to the 1960s and continues to evolve in depth and richness. It brings out many of the subtleties associated with the interlinkage of the multinational and host countries. These include, at the very outset of the volume, the role of the multinational firm as a change agent affecting an array of interests at various levels of aggregation. This is followed by a first-rate review of the conceptual foundations of the multinational enterprise. Both discussions are then brought to bear on the involvement of multinationals in South Africa under apartheid - one of the most complex and politically-charged stories in recent memory. In retrospect, did multinationals prolong or accelerate the demise of apartheid? And conversely, what was the impact of the political pressures exerted on them, in the US and elsewhere, to withdraw or modify their South African operations in the waning years of the old regime? There is, of course, no way to run the world twice, but the analysis provided by Professor Haley provides a solid foundation for thinking about such issues. The final part of the book focuses specifically on the issues of adaptation and withdrawal, 
xx Multinational Corporations in Political Environments

which are critical to an assessment of this question. For all of these reasons the book is likely to remain a valuable reference work on multinationals for years to come.

\author{
Ingo Walter \\ Charles Simon Professor of Applied Financial Economics \\ and Director, New York University Salomon Center \\ Stern School of Business \\ New York University
}




\section{By William D. Guth:}

There is considerable business and governmental interest in sanctions today, more than there was in the 1980s when multinational corporations in South Africa were the focus of organized stakeholder opposition. Stakeholder opposition continues against companies such as Nike, Shell and Disney and governments such as Myanmar's. Until the study reported in this book, however, all of the systematic research on sanctions had been done at the level of the nation state; at the level of the company, we had only anecdotal evidence. This is the first book that systematically studies why multinationals leave host states and the circumstances that prompt their leaving at the level of the company. Professor Haley has shed considerable new light on our understanding of the impact of stakeholder sanctions by including the values of top managers compared to those of other stakeholders as critical elements shaping companies' decisions. This important book identifies which sanctions by both governments and private pressure groups "work" and which do not, and explains why. It identifies the responses of corporate managements to these pressures, and demonstrates how frequently, and explains how and why, management turns situations that appear to be victories for the sanctioning parties into business-as-usual under a different format.

William D. Guth

Professor of Management and Strategy Stern School of Business New York University 
This page is intentionally left blank 


\section{Acknowledgements}

This book stems from my doctoral dissertation completed a decade ago at the Stern School of Business, New York University. Fascinated by newspaper reports and stakeholders' activism surrounding multinational corporations in South Africa, I was surprised to find that our existing theories did not explain adequately why multinationals left a country, how they left and in what form they left. I undertook the brave (or foolhardy) task of devising such an explanation. The dissertation took three years and extracted its toll in other respects too. Two years into its writing, the end appeared nowhere in sight. At that time, Professor Donald Lessard, visiting from MIT, was delivering an invited lecture on international business at Stern. Seeing this dejected, struggling and penurious doctoral student, Don stopped to provide some insights and encouragement. He said, "These years will soon be a memory and when you leave, you will be bombarded by opportunities. You will not have the time again, to think about one idea for three years as you are doing now. Take advantage of the moment."

Don's words have rung true. After leaving Stern, I was sucked into a whirlwind of opportunities to understand and to influence multinationals and governments in Italy, Mexico, Singapore, Malaysia, Australia, Vietnam, India, China and South Korea. I wrote over 70 books and journal articles, yet, never had the time to think about one idea, by itself, for six months let alone for three years. Recently, while discussing at Harvard efforts to 
xxiv Multinational Corporations in Political Environments

sanction Myanmar, and while correspondingly exploring with friend and activist Professor David Boje, efforts to pressure Nike, I was struck again by the applicability and freshness of the ideas I had explored earlier. This book is the result. I believe the ideas hold greater validity than they did a decade ago, as the benefits of hindsight have now come to bear as well as the opportunity to influence new developments.

The ideas in this book owe a great deal to the people who supported my efforts and provided guidance over the period of my dissertation as well as later through my professional career - Professors Ingo Walter and William Guth, who co-chaired my dissertation committee. Both Ingo and Bill generously provided the opportunity to explore concepts with them as well as commented copiously on rewrite after rewrite. Both provided their unique and stellar wisdom, knowledge and experience to the understanding and completion of this monumental book project. Both showed by example as well as deed that knowledge in business schools should aim to understand as well as to influence. Professors Thomas Pugel and Janice Beyer also provided many helpful comments on my dissertation over a decade ago, especially on the methodology, which I have incorporated in part into this book. To Ingo, Bill, Tom and Jan, I express my gratitude and thanks.

Others helped on this book project. Editor Karen Quek at World Scientific, read chapters and granted more time for the completion of this project when needed, supporting its goals from the outset. In the Management Department at the University of Tennessee, Knoxville, Professors Oscar Fowler and Michael Stahl contributed greatly to an intellectually stimulating environment that encourages scholarship and research on international and strategic issues. Ms. Jackie Cook and Ms. Jane Moser in the Management Department helped me with diagrams and tables in a timely and efficient fashion. Thank you, Karen, Oscar, Mike, Jackie and Jane.

On the home front, I owe thanks to my kittens, Comet Baby and Marmalade for making life more enjoyable and less stressful. Finally, I owe a debt of undying gratitude to my husband, George Haley, who put up 
with me during my dissertation and later, provided comments on the manuscript and moral and emotional support throughout. To George, I dedicate this book.

Usha C. V. Haley Associate Professor Department of Management College of Business Administration University of Tennessee, Knoxville 